\title{
Joining Militia; Understanding the Drivers of Militia Participation in Counterinsurgency Operation in Yobe State, Nigeria
}

Modu Lawan Gana

Department of Public Administration, Mai Idris Alooma Polytechnic, Geidam, Yobe State, Nigeria

ARTICLE INFO

Keywords:

Militia

Counterinsurgency

Boko Haram

\begin{abstract}
The Nigeria government has been fighting a protracted insurgency by Boko Haram since 2009. Despite the concerted multifaceted counterinsurgency approach, the insurgent sustained its violence with impunity. However, the participation of militia to support the government significantly suppressed the insurgent hostilities, reduced both attack frequencies and fatalities. Even though the militias succeed in the operation, but what motivates them to engage in the militia is not address. This article, therefore, drawing data from interviews and field observations, this study investigated the drivers of the militias in Yobe State. The case study is at Geidam involving 15 participants from three groups that include the militia participants, government officials, and community leaders. The find revealed poverty and unemployment are the key drivers of militias' participation in the operation. However, the study recommends that Nigeria and Yobe State governments should regulate the militia activities to avoid excessiveness. Nigeria's government should re-strategize its counterinsurgency campaign toward the people-centered operation. Others are the recruitment of more state counterinsurgent forces by the government.
\end{abstract}

\section{Introduction}

Since 2009, the Nigerian government has been fighting a protracted insurgency rebellion by an Islamist fundamentalist group Boko Haram. The colloquial 'Boko Haram' a derived from a Hausa, and the Arabic word 'school' and; forbidden' literally referred to, as western education is sacrilege. In its struggle, the group objects to all forms of civilizations including formal education and the secular state. It propagates for a total Islamic state by abolishing the constitutional regime and replacing it with an Islamic state that can be adjudicated through the spiritual injunction of the Qur'an and hadith, the holy books of Islam. The strategy of the group initially reflects on civil disobedience tactics such as subversion; sit-in, and hostilities toward state laws and actors. Others are isolations from the population. In 2003, angered by the urbanism and the growth of the democracy politic, the followers isolated themselves to a jungle in a remote community at Yobe State along the Nigeria and Niger Republic border to practice mundane life. Violent broke-out after an attempted police action to dislodge the movement. However, the group overpowered the police, killed two police officers, and looted the police armory. The looting of the armory laid the genesis of the groups' subsequent arm stock (Gana et al., 2018). The group however reached the climax of its violence in 2009 when some of its disgruntled members revolted in Maiduguri, a city of about 2 million population in vengeance against military and police brutality. The uprising in Maiduguri left about 2000 people left dead. The majority of the deaths are of the group members. Among them includes Mohammed

*Corresponding author E-mail address: gana.lawan@yahoo.com 
Yusuf, the spiritual leader, Buji Foi, the financier, and Baba Fuwu, the property owner hosting the groups' administrative office. Since then, the violence impetus of Boko Haram accelerates exponentially. The world refugee agency, United Nations Higher Commission on Refugee (UNHCR) documents that Boko Haram has killed nearly 30,000 people, displaced over 3 million as well as induces a massive humanitarian crisis for over 5 million populations within and across the shore of the Nigeria state. These damages incurred despite the counterinsurgency measures by the state.

However, despite the lackadaisical performance of the state measures, the involvement of the pro-government militias appeared significant in combating the decade-old insurgent rebellion. The group influences in harnessing relationships between the state authorities and the host communities. The militias are also a valuable source of human intelligence (HUMINT) providing timely intelligence about the insurgent movement and hideouts to the state officials. They equally play a force multiplier role. Since 2015 , the militias provide nearly $60 \%$ of the counterinsurgency mercenaries in the northeast (Hassan, 2015). The number has since been increasing. Bamidele (2015) estimates the number of militias at 15,000 spread across the six states of Nigeria northeast. Regarding their operational successes, Omenma and Hendricks (2018) revealed that the involvement of the militia reduced the mean attack rate of the insurgent by nearly half from 11.83 to 4.92 after the involvement. The militias are pointed out instrumental for the conquering many towns and villages occupied by the insurgent.

The incredible roles of the militia in routing the insurgent indicate a need not only to understand their origin, strategies, and tactics but also the key motivations triggering the participation. This article intends to intend to contribute to this perspective. The study besides the scholarly relevance is a policy science suitable for policymakers in Yobe state, Nigeria, and other countries sharing similar militia characteristics. In addressing this vacuum, the article proceeded in five sections. The first section addresses the methodological approach, section two presents the review of literature, section three present the drivers of the militia involvement in Yobe state, and four is the conclusion and recommendation of the study.

\section{Methodology}

\subsection{Research Design}

This research is approached on the qualitative method. The design is a case study. The case study was conducted in Yobe State of Northeast Nigeria. Yobe State is the second-worst affected states by the insurgent Boko Haram after Borno State. the state is a home town for the duo of Mohammed Yusuf and Abubakar Shekau, the ranked leaders of the Boko Haram. The violent impetus of insurgents was first noted in Yobe State when isolationist attacked police stations in Kanamma, Geidam, Dapchi, and Damaturu before repealed by the armies.

\subsection{Ethical Considerations}

Much in any qualitative research, this research is conducted through strict compliance with the ethical principles of a qualitative study. Universiti Putra Malaysia's ethical review committee testified for the integrity of the instrument. The approval has reference UPM/TNCPI /RMC/1.4.18.2. Moreover, for confidentiality and protecting the anonymity of the informants, pseudonyms replaced real participants' identities. For instance, pseudonyms A1 to A8 described militia, B1 to B4 refers to government representatives, and $\mathrm{C} 1$ to $\mathrm{C} 3$ described community/ traditional leaders. Besides, before the commencement of each interview session, the researcher explained the purpose of the research to each informant. Moreover, each of the participants' was duly notified about his voluntary participation. This also includes the rights to withdraw at any stage of the research process. To attest to the voluntary nature of the participation, each participant was asked to sign a consent form. 


\section{Literature Review}

Extant literature revealed that the phenomenon of militia involvement in counterinsurgency is on the verge of increase. Eastin and Zech (2019) show the presence of militias in eighty-eight countries that have actively engaged in four out of five civil wars between 1981 and 2007. The participation was witnessed not only by the weak and impoverished politically unstable countries but has reflected on the security arena of the world's best military and world superpowers. The cooptions of the Sunni Awakening Militia by the United States is one of the notable examples of the co-option of militias by the world powers. Another is the co-option of militias by Moscow to fight with the government during the Chechnya civil war. The literature shows when militias fought with the government, they reduced civilian casualty, enhances selective attacking of opponents, and destroying opponents' dens. Clayton \& Thomson (2014) showed that militias by their communal ties are effective in identifying insurgents and their sympathizers. The involvement of the Sunni Awakening group by the US armies assisted in successfully stemming the tide of the insurgent groups in the country. The group pointed out instrumental in restoring peace in different regions of Iraq including the most hostile Al-Anbar region of the country. Other regions where the group played a pivotal role according to Rineheart (2010) include the highly contested zones such as Salah-ad-Din and Diyala. Jones (2014) also revealed the incredible role of militias in suppressing drug pushing in Mexico. Switzer (2007) also reported the successes of the Rondas Campesina militias in Peru. Others are the success of Kamajos in Sierra Leone. The scholar argued that the mobilization of the group was influential in assisting the regular force in combating the rebels group.

Moreover, even though the participation of militia in counterinsurgency operations is effective in suppressing insurgent hostilities, the factors that drive the participation is not sufficiently address in the extant literature. This scenario has not only left a vacuum in the academic literature but has posed challenges to key policies about the militias and their operating environment.

\subsection{Drivers of Militia Involvement in Counterinsurgency in Yobe State}

The data revealed two themes of incentivization factor and psychological factors as the key drivers of people involved in the militia movement. The incentive factors for the participation of militia as revealed by the informants are of two categories comprising pecuniary incentives and non-pecuniary incentives. The pecuniary incentive refers to tangible rewards of monetary and material goods received by the participants for their operation. The non-pecuniary incentive, on the other hand, refers to incentives that relate to non-tangible goods such as expectations of employability and or expected reward at the course of retirement. In this respect, the informants suggest that they engaged in the militia because they have a lot to gain from the group. Reflecting on this contention, for instance, informant A2 explained: we received monthly stipends of 30000 Naira monthly since recruitment. Another informant (Informant C3) supports that the militias receive a monthly stipend of about 30,000 (\$83) from the local authorities. This payment according to the informants started accruing to the members one year after the mobilization of the group. Reflecting on this contention, informant A1 explained:

Since 2015, we have been receiving an allowance of 30,000 through the local government and state ministry. This is a very big amount if you compare to those working with the local government. Despite their school certificates, many people I know are collecting 17,000 Naira as basic salary and others even less than this. Therefore, because of these expectations, everybody is interested to join the movement. 
In addition to the direct monetary incentive, participants were equally offered three square meals in their camp settings. Although, even as the informants' opinion differs concerning the quantities and the qualities of the meals, but the majority of the respondents show enthusiasm to the gesture. Informant $\mathrm{C} 2$ reacted to this assertion;

We believe the quantity and the quality of the food offered may not be the test of many of them, we look at the hardship induced by the food shortage as the result of the insurgency, it is still appreciating by many people.

Some informants indicated opportunities for food aids by government and non-governmental organizations are the drivers of their participation in the militia work. Informant A1 described: Our participation has created chances of collecting food aids from Nongovernmental Organizations like World Food Programme; COOPI, Action against Hunger, and Red Cross. To this date, many of our members are enrolled on the list of these food donors. Informant A5 also supported;

There is a better chance of obtaining once you are in the CJTF than being private. Before I participate in the CJTF, I rarely get a single chance, even in the event of three different distributions. Now, I am accessing almost all distribution. Not just for myself, I am capable of enhancing means for others.

Observation during the fieldwork also confirmed the collection of aid services by members of the CJTF group. On several occasions, members of the CJTF sighted in aid centers of organizations such as Cooperazone International, World Food Program, and the United Nations International Children, Education Fund [UNICEF] providing security and assisting in beneficiary's organizations. Militias equally receive incentives rendering special services to key community members such as escorting of traditional rulers, securing the premises of public gathering; marriages; burials, and prayer grounds. In most instances, the services are not negotiable; however, such emolument has significantly contributed to the participating of people in the militia group. These motivations of the militia participation confirmed Olson (1971) that claimed the availability of personal benefit for participation.

In most respect, the participation of people in the militia is linked to the disheartening unemployment in northeastern Nigeria. Many studies have attested to the intricate relationship between poverty and violent conflict situation (Onuoha, 2013; Bamidele, 2015; Justina, 2011). All these studies maintained that a population devastated by extreme poverty can easily drive into violent conflict. Collier and Hoeffler (2001) using data on 45 different civil wars between 1960 and 2011 discover economic motivation as the most contributing factor for militia participation far more than the grievance factors. They term the motivation as 'opportunism' implying the availability of finance for recruits determines the interest of participation. These contentions significantly reflected the present interest of the CJTF participants as found by this study

Consequently, the pecuniary motivations of CJTF conformed to the greed theory of militia mobilization in counterinsurgency operations popularized by Collier (2008). It also corroborates with Nussio (2012), as well as Nussio \& Ugarriza (2013), whose differential studies of motivations of anti-rebel force in Columbia show financial and material incentives as the triggering factors. More so, Humphreys \& Weinstein (2008) in their analysis of paramilitary motivations shows economic as among the popular incentives for participation. The empirical work of Collier and Hoeffler (2001) using data of 45 civil wars between 1960 and 2011 revealed economic motives as the key driver for militia engagement in violent conflict. Moreover, in their study of pro-Moscow militia in Ukraine, Malyrenko and Galbreath (2016) show socioeconomic factors prompted the participation of the group. The finding also 
corroborates with Nussio (2012), as well as Nussio \& Ugarriza (2013), their studies of the motivations of anti-rebel force in Columbia revealed financial and material incentives as the drivers of militia participation in the country. There is a popular belief that during the period of detestable conflict, people choose to participate in militarism not only for the opportunity factors but equally to ensure survival (Humphreys and Weinstein 2008).

The finding however contrasts Cramer (2010) that shows discrimination rather than aggregate unemployment and poverty as the driver of militia engagements in paramilitary gangs in Northern Ireland. In his analysis of the motivations of militia participation in Sierra Leone, Keen (2005) revealed unemployment is not the only motivation of recruits, but resentment due to class politics and social discrimination as the driving forces. Berman et al., (2009) claimed unemployment does not significantly explain the participation of pro-government militia in Iraq and the Philippines rather grievance of increasing threat and poor protections by the state. Nevertheless, there is a general belief that offering incentives for militia undermine the termination of violence. Militias would sabotage peace processes, scare people, scuttle dialogue, and spread fake news to provoke a public uprising against the constituted authorities. These situations should be possible by their proximity and local identities. Clayton (2014) has documented this scenario in the case of the Janjaweed's militias in South Sudan. The private interest of looting, cattle rustling, and forces marriages entice militants to scuttle peace processes. Moreover, the militias would sometimes deliberately supply faulty intelligence to regular force thus sabotaging State operation. Furthermore, some militias tend to politicize their campaign by engaging in political thuggery (Peic, 2014; Ahram, 2014; Raleigh and Kishi, 2018). Gurur (2013) have equally reported this challenge with the Raia Mutomboki militias in the Democratic Republic of Congo. Initially influential in combating the rebels, however, the group has subsequently found gullible on several waves of abuse bordering on human rights, liberties, and war crimes.

Evidence from the fieldwork and scholarly literature suggests that violent impetus cannot be dismissed with the militia groups in Nigeria. For instance, Harnischfeger (2003) has revealed the militarization of the Bakassi Boys in southeastern Nigeria. The group like the present counter Boko Haram militia formed to protect the communal security interest but subsequently challenge the autonomy of the state. They are used as political thugs targeting allege political opponents of their paymasters. They intimidate civilians and engaged in extra-legal activities. In nutshell, field data suggest potential threat symptoms with the militia participants. Militias advocate for the continuing violence describing the termination of the insurgency may result in the cancellation of the attendant benefits of the participation.

\section{Conclusion}

Fundamentally, the case study revealed a combination of personal motivations and incentive factors as main drivers of the participation of people in the militia movement in Yobe state. These kinds of motivations conform to the assertion of Humphrey and Weinstein (2008). According to Weinstein, people are attracted to paramilitary force because of material gains. Therefore, the biggest attraction of the participants to the paramilitary exercise is the expectation of a steady paycheck. Participants indicated that becoming a militia enhances the ability to eke out stipends from both government institutions, and other humanitarian bodies. Precisely, the finding supports incentive-based explanations of militia engagement in civil violence promoted by Malcur Olson's theory. There is limited data exist on certain rationality factors as promoted by Nussio and Origaza (2013) in the case of the Columbia paramilitary participation. The decision to join and withdraw is solely determined by the availability of the incentive meant for the participant. In this respect, the finding argues that the unprecedented participation of the people in the group despite the attendant risk is connected to the mindboggling poverty and economic crisis inhibiting the localities. Although massive poverty 
and unemployment have been ahistorical in Nigeria's northeast, it was exaggerated by the decade old of the insurgent rebellion.

Regarding the operational successes of the group, the study found protracted commitment including access to first-hand and timely intelligence influence its operation. This is largely facilitated by the militias' socio-cultural connections and technical knowledge of the physical terrains including all the creeks, hills, and forest hibernating the insurgent group. In nutshell, the study argues that the inadequate knowledge of the socio-cultural values of the host population coupled with the prioritizations of the enemy-centric approach in the combating processes. The indiscriminate military aggression and repressive state policies undermined the successes of the state base counterinsurgency.

Therefore, arising from the desperation of the militias for personal material goods gains. This article suggests a decisive measure to regulate the militia activities, they will constitute another security challenge to the region. They will change to opportunist militias to be used as political thugs by their paymasters thus lynch violence on people perceived to be political opponents. This situation can be made possible in the absence of strong regulatory mechanisms by the government. In this respect, the article recommends that to checkmate the excessiveness of the militia and confine their operation to establish norms of the society, the Yobe State government and Nigeria should promulgate an act to regulate the militia activities. Moreover, the Nigerian government should re-strategize its counterinsurgency tactics toward the people-centered campaign. The present strategize is largely focused on the enemy-centric approach. The consequences of the enemy-centrism are that it is capable of undermining the communal support toward the force and its operation. The extended effect of this thus undermines the counterinsurgents' access to timely and credible intelligence. Moreover, since it is evident that the size of the state-owned counterinsurgent force is inadequate, the government should recruit formal security forces. The over-reliance on the militia may result in moral hazard for the government. In fact, as militias seemingly loyal to their communities and spiritual leaders, their prolongation in the state function can result in the state losing its autonomy in the long run; an idea that cannot argue well for the Yobe state government and the country at large.

\section{Acknowledgements}

The author would like to thank the Tertiary Education Trust Fund (TETfund) in Nigeria for worthy of supporting the research. Thank you, the Management of Mai Idris Alooma Polytechnic, Geidam for recommending the study to the TETfund. Special thanks to all the research participants that took time to give valuable information to the researcher.

\section{References}

Agbiboa, D. (2015). Resistance to Boko Haram: Civilian Joint Task Forces in North-Eastern Nigeria Conflict Studies Quarterly. Conflict Studies Quarterly, Special Issue 3-22.

Ahram, A. I. (2014). The Role of State-Sponsored Militias in Genocide, Terrorism and Political Violence, Vol. 26.3, pp. 488-503

Al-Efendi, A \& Gumel, S. (2015). Abducting Modernity: Boko Haram, Gender Violence and the Marketplace of Bigotry. Journal of Women of the Middle East and the Islamic World, Vol. 13, pp. 127-140.

Ali, M. A., Bubaram, F.U \& Adamu, A (2018). The Negative Impacts of Boko Haram Insurgency on Northern Nigeria. IOSR Journal of Humanities and Social Science, Vol. 23.7, pp. $72-80$.

Bamidele, O. (2015). Beyond the Shadows of Terrorism: Boko Haram Crisis in North-Eastern Nigeria. Conflict Studies Quarterly, Special Issue, pp. 41-57. 
Bamidele, O. (2016). Civilian Joint Task Force' (CJTF) - A Community Security Option: A Comprehensive and Proactive Strategy to Counter-Terrorism. Journal for Deradicalization, Vol. 7, pp. 124-144.

Berman, E., Joseph F \& Jacob N. S. (2009), "Do Working Men Rebel? Insurgency and Unemployment in Iraq and the Philippines", Working Paper Series, 15547, NBER Cambridge, Mass: National Bureau of Economic Research.

Clayton, G \&Thomson, A. (2014). The Enemy of My Enemy is My Friend ... The Dynamics of Self-Defence Forces in Irregular War: The Case of the Sons of Iraq. Studies in Conflict \& Terrorism, Vol. 37.11, pp. 920-935

Clayton, G \&Thomson, A. (2014). The Enemy of My Enemy is My Friend ... The Dynamics of Self-Defence Forces in Irregular War: The Case of the Sons of Iraq. Studies in Conflict \& Terrorism, Vol. 37.11, pp. 920-935

Collier, P \& Hoeffler, A. (2004). Greed and Grievance in Civil War. Oxford Economic Papers, Vol. 56, pp. 563-595.

Cramer, C. (2010). Unemployment and Participation in Violence, World Development Report Background Paper, http://web.worldbank.org/archive/website01306/web/pdf/wdr\% 20background\%20paper\%20-\%20cramer.pdf

Eastin, J \& Zech, S.T (2019): Joining the Counterinsurgency: Explaining Pro-Government Militia Participation in the Philippines, Studies in Conflict \& Terrorism, p.1-25 DOI: 10.1080/1057610X.2019.1700029

Emuedo, C.O., Oghaotor, H \& Abam, M. (2015). Elites Predation and Insecurity: A Perspective on the Boko Haram Insurgency in Nigeria. Global Journal of Human-Social Science: F Political Science, Vol. 15.5, pp. 24-38

Gana L.M., (2020). Strategy Of Civilian Joint Task Force Militia in Combating Boko Haram in Northern Nigeria; International Journal of Legal Studies, Vol.1(7), 345 - 360 Doi: $10.5604 / 01.3001 .0014 .3126$

Gana M.L. (2020). Militia Counterinsurgency: Perspective on the Motivations of Civilian Joint Task Force Militia Participation in Northern Nigeria. RUDN Journal of Public Administration vol. 7 (2): 124-134. DOI: 10.22363/2312-8313-2020-7-2-124-134

Gana, M.L., Samsu, K.H \& Ismail, M.M. (2018b). Population-Centric Counterinsurgency: The Conduit for Ending Boko Haram Insurgency in Nigeria's North. European Journal of Behavioral Sciences, 1 (4): 8-13.

Gorur, A. (2013). Community Self-Protection Strategies: How Peacekeepers Can Help or Harm. Civilian in Conflict Policy Brief No. 1

Hassan, I. (2015). Counter-Insurgency from Below, the Need for Local Grassroots Defenders in Curbing the Insurgency in Northeast Nigeria, West African Insight.

Jones, S.G. (2012). The Strategic Logic of Militia, National Defence Research Institute, Working Paper, WR-913-SOCOM

Justina, P. (2011). Poverty and Violent Conflict: A Micro-Level Perspective on the Causes and Duration of Warfare. IDS Working Paper 385, Institute of Development Studies

Keen, D. (2005), Conflict and Collusion in Sierra Leone, Oxford: JamesCurrey 
Malyarenko, T \& Galbreath, D.J. (2016). Paramilitary Motivation in Ukraine: Beyond Integration and Abolition, Southeast European and Black Sea Studies, pp. 1-27 DOI:10.1080/14683857.2016.1148414.

Mohammed, K. (2014). The Message and Methods of Boko Haram In: M-A, Perouse de Montclos (Eds) Boko Haram: Islamism, Politics, Security and the State in Nigeria, African Studies Centre, Leiden, France, pp. 9-32

Nussio, E \& Ugarriza, J (2013). Are Insurgents Any Different from Counterinsurgents? A Systematic Integration and Validation of Motivational Studies from Colombia.

Nussio, E. (2012). Emotional Legacies of War among Former Columbian Paramilitaries. Peace and Conflict: Journal of Peace Psychology, Vol. 18.4, pp. 369-383

Olson, M. (1965). The Logic of Collective Action. Public Goods and the Theory of Groups. Cambridge, MA: Harvard University Press.

Omenma, J.T \& Hendricks, C.M (2018). Counterterrorism in Africa: An Analysis of the Civilian Joint Task Force and Military Partnership in Nigeria. Security Journal, 31(3), 764-794.

Onuoha, C.F (2014). A Danger not to Nigeria Alone. Boko Haram's Transnational Reach and Regional Response. Fredrick Stifung Regional Office, Abuja

Onuoha, F. C. (2012). Reports Boko Haram: Nigeria's Extremist Islamic Sect. Al-Jazeera Centre for Studies.

Peic, G (2014). Civilian Defence Forces, State Capacity, and Government Victory in Counterinsurgency Wars. Studies in Conflict \& Terrorism, Vol. 37. 2, pp. 162-184.

Pérouse de Montclos, M.-A. (2016). A Sectarian Jihad in Nigeria: The Case of Boko Haram. Small Wars \& Insurgencies, Vol. 27. 5, pp. 878-895.

Raleigh, C \& Kishi, R. (2018): Hired Guns: Using Pro-Government Militias for Political Competition, Terrorism and Political Violence, pp. 1-22. doi: 10.1080/09546553. 2017.1388793.

Rineheart, J (2010). Counterterrorism and Counterinsurgency, Perspective on Terrorism, Vol. 4.5 , pp. 23-27.

Switzer, R. W. (2007). Sendero Luminoso and Peruvian counterinsurgency. LSU Master's Theses. 1816. 